\title{
Steer performance on deferred pastures of Brachiaria brizantha and Brachiaria decumbens
}

\author{
Desempenho de novilhos de corte em pastos diferidos de \\ Brachiaria brizantha e Brachiaria decumbens
}

\section{Camile Sanches Silva ${ }^{I}$ Denise Baptaglin Montagner ${ }^{I{ }^{*}}$ Valéria Pacheco Batista Euclides ${ }^{\text {II }}$ Carolina de Arruda Queiroz ${ }^{\text {III }}$ Rafael Augusto Silva Andrade ${ }^{\mathrm{I}}$}

\section{ABSTRACT}

The objective of this study was to compare structural, morphological and bromatological characteristics of forage as well as performance of Caracu beef cattle $(200 \pm 9 \mathrm{~kg}$ of initial body weight) supplemented with a multi-mineral mixture $(0.25 \%$ of body weight) on deferred pastures of Brachiaria brizantha 'Marandu' and Brachiaria decumbens 'Basilisk' under continuous grazing. After the pasture was grazed to $10 \mathrm{~cm}$ of height, in March 2014, both grasses were left to rest and subjected to a 126-day deferment period. The experimental period lasted from July to October 2014; the sward characteristics and the animal's weight were evaluated every 28 days. The highest forage mass was recorded in 'Marandu' grass, whereas the highest leaves percentage and lowest dead material percentage were observed in 'Basilisk' pastures. Similarly, the highest crude protein content ( $8.1 \mathrm{vs} .7 .0 \pm$ $0.2 \%)$, in vitro organic matter digestibility (57.7 vs. $53.9 \pm 0.4 \%)$, lowest neutral detergent fiber content (69.2 vs. $72.7 \pm 0.4 \%)$, and; consequently, the highest average daily gain (680 vs. $530 \pm 0.04 \mathrm{~g}$ animal $\left.{ }^{-1}\right)$ were recorded for 'Basilisk' pastures. 'Marandu' and 'Basilisk' deferment was associated with a multi-mineral mixture supplementation as a management alternative for rearing beef cattle during the drought periods. Because of the duration of the pasture recovery period in this study, B. decumbens pastures were more likely to achieve the highest animal performance.

Key words: dry season, multi-mineral mixture, canopy structure, nutritive value.

\section{RESUMO}

$O$ objetivo deste trabalho foi comparar as características estruturais, morfológicas e bromatológicas da forragem e o desempenho de bovinos de corte, da raça Caracu (200土9kg de peso inicial), suplementados com mistura mineral múltipla $(0,25 \%$ do peso corporal) em pastos diferidos de
Brachiaria brizantha, cv. 'Marandu', e Brachiaria decumbens, cv. 'Basilisk', sob pastejo contínuo. Após o rebaixamento dos pastos a $10 \mathrm{~cm}$ de altura, realizado em março de 2014 por meio de pastejo, ambas as espécies foram vedadas e diferidas por 126 dias. O periodo experimental foi de julho a outubro de 2014, e as avaliações das características do pasto e as pesagens dos animais foram realizadas a cada 28 dias. A maior massa de forragem foi registrada em pastos de 'Marandu'. A maior porcentagem de folhas e a menor de material morto foram observadas para a 'Basilisk'. Os maiores teores de proteina bruta (8,1 vs 7,0 $\pm 0,2 \%)$, digestibilidade in vitro da matéria orgânica $(57,7$ vs $53,9 \pm 0,4 \%)$, os menores teores de fibra em detergente neutro (69,2 vs 72,7 \pm $0,4 \%$ ) e, consequentemente, o maior ganho médio diário (680 vs $530 \pm 0,04 \mathrm{~g}_{\left.\text {animal }^{-1}\right)}$ foram registrados para a $\mathrm{cv}$. 'Basilisk'. O diferimento de pastagens de 'Marandu' ou 'Basilisk' associado à suplementação com mistura mineral múltipla figura como alternativa de manejo para recria de bovinos de corte durante o periodo seco. Para a duração do período de vedação utilizada, pastos de B. decumbens são mais indicados para alcançar o maior desempenho animal.

Palavras-chave: estação seca, mistura mineral múltipla, estrutura do dossel, valor nutritivo.

\section{INTRODUCTION}

Brachiaria brizantha and Brachiaria decumbens play an important role as forage source for ruminants once they adapt to a wide range of soils and are resistant to seasonal droughts than others tropical perennial grasses (VALLE et al., 2010). During dry season, water shortage or low temperatures limits the pasture growth. In this period, the adoption

IPrograma de Pós-graduação em Zootecnia, Universidade Federal da Grande Dourados (UFGD), Dourados, MS, Brasil.

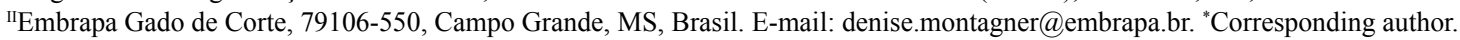

IIIPrograma de Pós-graduação em Ciência Animal, Universidade Federal de Mato Grosso do Sul (UFMS), Campo Grande, MS, Brasil. 
of alternative grazing management techniques as stocking rate adjustments, irrigation in areas where this practice is recommended, supplemental feeding (REIS et al., 2012) or deferred grazing (EUCLIDES et al., 2007) may reduce the impact of nutritional deficiency and might ensure adequate food supply.

$B$. brizantha and $B$. decumbens pastures exhibit some characteristics that make them suitable for deferred-type grazing system. These includes potential for herbage accumulation during the end of summer and beginning of dry season and a slow decreasing in nutritional value throughout the deferment period (EUCLIDES et al., 2007). The adoption of deferred-type grazing system may favor herbage accumulation for scarcity periods. However, the quality of forage produced is an important limiting factor for animal performance. According EUCLIDES et al. (2014) weaned calves maintained in deferred pastures needs dietary supplementation to reach slaughter weight between 18 and 24 months. Thus, additional sources of protein, energy and minerals through supplemental feeding are necessary to ensure animal weight gain (REIS et al., 2012).

To make the deferred grazing system viable, dietary supplementation of feed for weaned calves in the beginning of the dry period is essential for them to reach slaughter weight between 18 and 24 months of age (EUCLIDES et al., 2014). Current study evaluates the structural, morphological and bromatological characteristics in deferred pastures of Brachiaria brizantha cv. 'Marandu' and Brachiaria decumbens cv. 'Basilisk' and performance of beef steers supplemented with a multi-mineral mixture.

\section{MATERIALS AND METHODS}

The study was carried out in Embrapa Beef Cattle experimental area, Campo Grande-MS $\left(20^{\circ} 27^{\prime}\right.$ $\mathrm{S}$ and $54^{\circ} 37^{\prime} \mathrm{W}$, altitude $530 \mathrm{~m}$ ), from July to October 2014. According to Köppen, the region climate is classified as AW tropical wet, with well-defined rainy (October to April) and dry seasons (May to September). Precipitation and minimum, average, and maximum temperatures during the experimental period and the average monthly precipitation from the last 30 years were recorded by the weather station of Embrapa Beef Cattle (Figure 1A). The average temperature and monthly precipitation were used to calculate water balance (Figure 1B). The soil water storage capacity was determined to be $75 \mathrm{~mm}$.

The soil was classified as dystrophic red latosol with a clay texture (FAO, 2006). Marandu grass (B. brizantha 'Marandu') and signal grass
(B. decumbens 'Basilisk') pastures were recovered in 1994. Maintenance fertilization was realized in these swards every three years (EUCLIDES et al., 2009). The experimental soil was analyzed at $0-20 \mathrm{~cm}$ depth and the results were: $\mathrm{pH}\left(\mathrm{CaCl}_{2}\right)=5.9 ; \mathrm{pH}$ water $=6.5$; P-Mehlich1 $\left(\mathrm{mg} \mathrm{dm}^{-3}\right)=6.0$; organic matter $(\%)=3.9$; $\mathrm{K}\left(\mathrm{cmol}_{\mathrm{c}} \mathrm{dm}^{-3}\right)=0.4 ; \mathrm{Ca}\left(\mathrm{cmol} \mathrm{dm}^{-3}\right)=4.3 ; \mathrm{Mg}\left(\mathrm{cmol}_{\mathrm{c}}\right.$ $\left.\mathrm{dm}^{-3}\right)=1.4 ; \mathrm{Al}\left(\mathrm{cmol}_{\mathrm{c}} \mathrm{dm}^{-3}\right)=0.0$; sum of bases $\left(\mathrm{cmol}_{\mathrm{c}}\right.$ $\left.\mathrm{dm}^{-3}\right)=6.1$; effective CEC $\left(\mathrm{cmol}_{\mathrm{c}} \mathrm{dm}^{-3}\right)=9.1$; and base saturation $(\%)=67.0$. Based in this analysis, in January 2012 , pastures were fertilized on the cover with $40 \mathrm{~kg}$ ha $^{-1}$ of $\mathrm{P}_{2} \mathrm{O}_{5}$, and $40 \mathrm{~kg} \mathrm{ha}^{-1}$ of $\mathrm{K}_{2} \mathrm{O}$.

The experimental area was formed by two 1.5-ha paddocks for each forage species, allocated into two blocks, totaling 6.0ha. In the previous rainy period, pastures were subjected to continuous stocking maintained approximately 1.5 animal units (AU) ha ${ }^{-1}$. On March 2014 the pastures were subjected to a heavy grazing since $10 \mathrm{~cm}$ of sward height. After that, $50 \mathrm{~kg} \mathrm{ha}^{-1}$ of $\mathrm{N}$ was top-dressed on the experimental area and both forage species were left to rest and subjected to a 126-day deferment period.

The experimental area was formed by two 1.5-ha paddocks for each forage species, allocated into two blocks, totaling 6.0 ha. In the previous rainy period, pastures were subjected to continuous stocking maintained approximately 1.5 animal units (AU) ha-1. In March 2014, the stocking rate was increased, in order to lower the canopy height to $10 \mathrm{~cm}$, and the pastures were deferred. Thereafter, nitrogen fertilization was performed with $50 \mathrm{~kg} \mathrm{ha}^{-1}$ of $\mathrm{N}$, in the form of urea. Pastures remained deferred for 126-day, and during the dry period they were continuously stocked.

The experimental design was a randomized complete blocks, with two treatments and two replicates presented by Brachiaria brizantha cv. 'Marandu' and Brachiaria decumbens 'Basilisk' pastures submitted to deferral procedure. In in July 2014, seven Caracu weaned calves, of approximately eight months of age with an average initial weight of $200 \pm 9.5 \mathrm{~kg}$, were placed in each paddock. Animals were assigned randomly to experimental units; the differences in allocation weight across treatments were not significant at the beginning of experimental period, and the animals remained in the same pasture for the entire experimental period. Grazing system used was continuous stocking and fixed stocking rate (equivalent to $2.1 \mathrm{AU} \mathrm{ha} \mathrm{h}^{-1}$ in the beginning of the experimental period). All paddocks had an opened feeder and a trough with ad libitum access to water. 


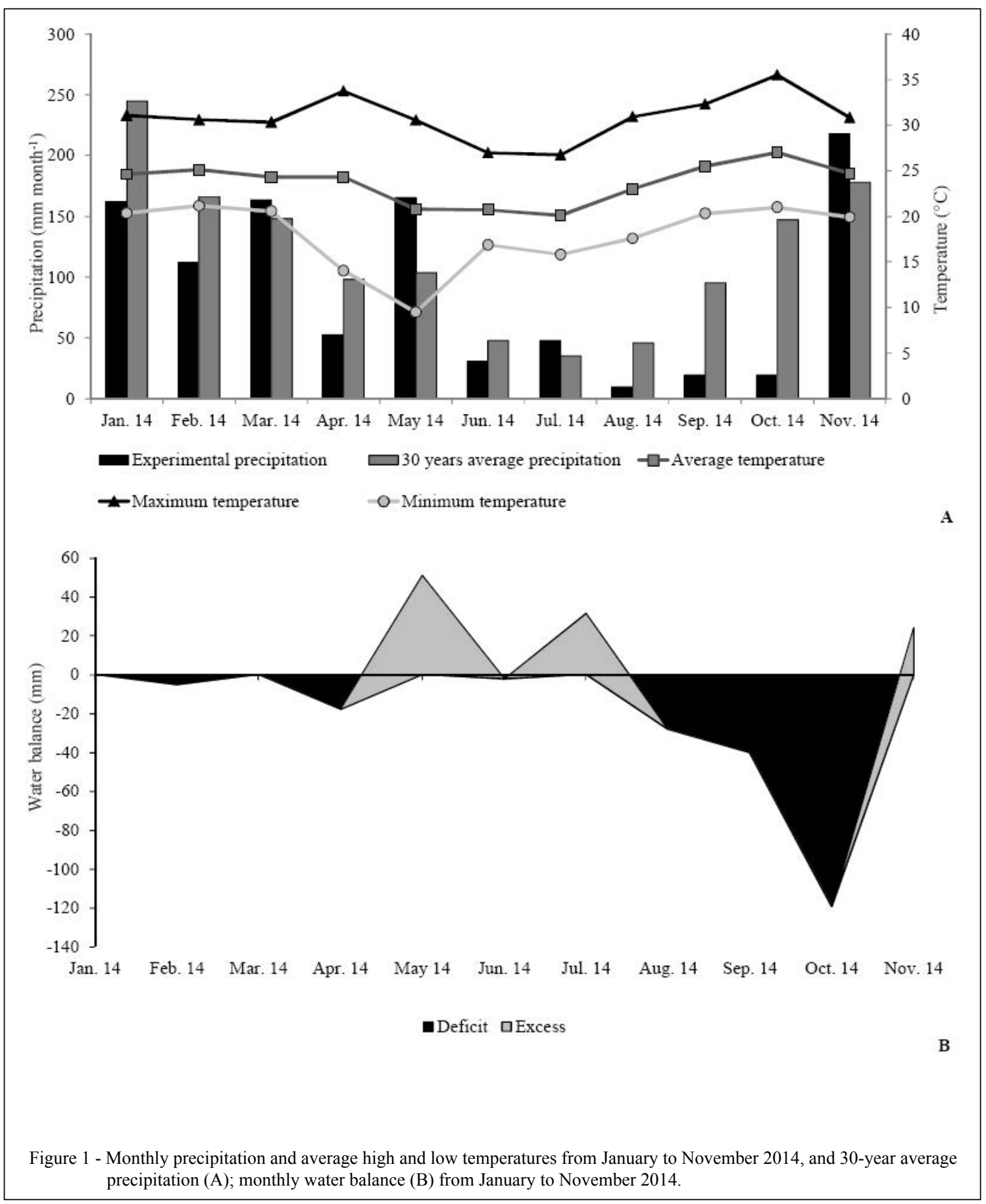

All animals were supplemented with a multi-mineral mixture, given at a quantity equivalent to $0.25 \%$ of the animal's body weight, containing $28 \%$ soybean meal, $8 \%$ urea, $52 \%$ milled corn grain, $7 \%$ mineral salt, and 5\% sodium chloride (crude protein $=39.6 \%$; total digestible nutrients $=68.4 \%$ ).
Supplement formulation and its bromatological composition were obtained using the Embrapa Invernada program (BARIONI, 2011). The supplement was provided daily at 8:00 a.m. When there was supplement leftovers, it was weighed to estimate supplement intake. Every 28-day at 
the time of the animals weighing the supplement amount was adjusted.

The animals were weighed after fasting for 16 hours. Average daily weight gain (ADG) was determined by the difference in animal weight between the beginning and end of each period, divided by the number of days between weighing. Weight gain per area was obtained by multiplying the average daily gain of the animals by the number of animals maintained in each paddock and the number of days.

Every 28 days, 15 samples $\left(1 \mathrm{~m}^{2}\right)$ were randomly selected and cut at ground level in each paddock. Samples were divided into two sub-samples. One sub-sample was weighed, placed in paper bags, dried in a forced air ventilation oven at $65^{\circ} \mathrm{C}$ until constant weight was achieved and weighed again for estimation of the herbage mass. Composite samples were obtained by combining five sub-samples and separated into leaf (leaf blade), stem (stem and sheath) and dead material; the percentage of the total weight for each component was determined.

To estimate the nutritional value of the forage, two samples were collected simulating the grazing in each paddock on the same day the forage mass was determined. These samples were dried to a constant weight in a forced-air oven at $65^{\circ} \mathrm{C}$, milled, and analyzed to determine the crude protein percentages, in vitro organic matter digestibility, neutral detergent fiber, and acid detergent lignin by near-infrared spectroscopy (NIRS).

Data set were grouped as follow: period 1 = July 14 to August 11, 2014; period 2 = August 12 to September 8, 2014; period $3=$ September 9 to October 6,2014 . The data were analyzed using multivariate repeated measures analysis according to LITTELL et al. (2000), using PROC MIXED in SAS ${ }^{\circledR}$ (Statistical Analysis System), version 9.4, Windows ${ }^{\circledR}$. The variance and covariance matrices tested were AR(1), ARH(1), ARMA (1,1), CS, UN, HF, VC, TOEP, and TOEPH, and were chosen based on the Akaike information criterion (AIC) (WOLFINGER, 1993). The applied model included the random effect of the blocks and the fixed effects of the grass species, evaluation period and their interactions. Period was considered repeated measures. Means were compared, when appropriated, with Tukey test $(\mathrm{P}<0.05)$.

\section{RESULTS AND DISCUSSION}

The forage species and evaluation period affected canopy height, forage mass (FM), leaf mass (LM), percentages of leaves (PL), dead material (PD), crude protein $(\mathrm{CP})$, in vitro organic matter digestibility (IVOMD), and average daily gain (Table 1 and Table 2). Conversely, neutral detergent fiber (NDF) content was only affected by forage species (Table 2). Stem percentage and forage allowance varied only with evaluation period (Table 1). The acid detergent lignin content (ADL) was not influenced either by forage species or by periods. The average value was $3.0 \pm 0.13 \%$. Furthermore, no forage species and evaluation period interaction $(\mathrm{P}>0.05)$ was detected for any of the variables studied.

Forage mass, forage allowance and stem percentage decreased throughout the experimental period (Table 1). Conversely, canopy height, leaf percentage and leaf mass decreased from de first to the second periods and thereafter increased (Table 1). The opposite was observed for dead material percentage, which, increase from the first to the second period, and decrease from the second to the third period (Table 1).

Although the lowest FM was registered in the third evaluation period (September and October), an increase in leaf percentage was observed. Resulting in an increase in the leaf mass (Table 1). In addition, during the last period there were decreases in the stem and dead material percentages (Table 1).

Those variations in canopy structure throughout the experimental period (Table 1) could be explained by the more favorable weather conditions (Figure 1A). In spite of the precipitation of approximately $40 \mathrm{~mm}$, registered in the third period (September and October), it was not enough to restore the water levels in the soil (Figure 1B), being; however, sufficient to initiate the processes of leaf emergence and elongation (NELSON, 2000).

The variation patterns of the $\mathrm{CP}$ content and IVOMD percentage in samples simulated grazing by animals, over the experimental period, followed the same pattern of variation of PL, and the inverse of PD variation pattern (Table 1). Conversely, NDF and ADL contents did not vary with evaluation period, the averages ( \pm standard errors) were, respectively, $70.9 \pm 0.4$ and $3.0 \pm 0.1 \%$.

Besides the changes in canopy structure mentioned above, the decreases in the percentages of CP and IVOMD, from the first to the second period, could be explained by the aging of the forage plant. Since, as the plant matures, the concentration of rapidly digestible components, including soluble carbohydrates, protein, and minerals, tends to decrease; thus, a decrease in digestibility is expected (VAN SOEST, 1994). Conversely, the increases in the percentages of CP and IVOMD, from the second to the third period, could be explained by pasture 
Table 1 - Averages, standard error of the mean (SEM) and significance level (p) for canopy height, forage mass, leaf mass, forage allowance (FA), percentages do leaf, stem and dead material, percentages of crude protein and in vitro organic matter digestibility (IVOMD), and average daily gain (ADG) in signal grass and marandu grass pastures deferred in March and grazed from July to October 2014.

\begin{tabular}{|c|c|c|c|c|c|}
\hline & Period 1 & Period 2 & Period 3 & SEM & $\mathrm{P}$ \\
\hline Canopy height $(\mathrm{cm})$ & $28.1 \mathrm{~b}$ & $29.0 \mathrm{~b}$ & $39.2 \mathrm{a}$ & 2,1 & 0.0045 \\
\hline Forage mass $\left(\mathrm{kg} \mathrm{ha}^{-1}\right.$ of $\left.\mathrm{DM}\right)$ & $2.880 \mathrm{a}$ & $2.680 \mathrm{ab}$ & $2.440 \mathrm{~b}$ & 69.7 & 0.0069 \\
\hline Leaf mass $\left(\mathrm{kg} \mathrm{ha}^{-1}\right.$ of DM) & $735 \mathrm{a}$ & $370 \mathrm{~b}$ & $570 \mathrm{ab}$ & 4.6 & 0.0034 \\
\hline FA (kg of DM per $100 \mathrm{~kg}$ of LW) & $9.8 \mathrm{a}$ & $9.1 \mathrm{a}$ & $7.7 b$ & 0.4 & 0.0341 \\
\hline Leaf $(\%)$ & $26.0 \mathrm{a}$ & $14.0 \mathrm{~b}$ & $24.2 \mathrm{ab}$ & 2.4 & 0.0295 \\
\hline Stem $(\%)$ & $22.5 \mathrm{a}$ & $19.5 \mathrm{ab}$ & $17.6 \mathrm{~b}$ & 1.2 & 0.0488 \\
\hline Dead material (\%) & $51.5 b$ & $70.3 \mathrm{a}$ & $58.2 \mathrm{ab}$ & 2.9 & 0.0042 \\
\hline Crude protein $(\%)$ & $7.2 \mathrm{~b}$ & $6.6 \mathrm{c}$ & $8.3 \mathrm{a}$ & 1.2 & 0.0001 \\
\hline IVOMD (\%) & $55.8 \mathrm{~b}$ & $53.2 \mathrm{~b}$ & $58.3 \mathrm{a}$ & 0.6 & 0.0031 \\
\hline ADG (g animal ${ }^{-1}$ day $\left.^{-1}\right)$ & $590 \mathrm{~b}$ & $490 \mathrm{c}$ & $725 a$ & 38 & 0.0001 \\
\hline
\end{tabular}

Averages in the same row followed by different letters differ $(\mathrm{P}<0.05)$ by Tukey's test.

$\mathrm{DM}=$ dry matter; $\mathrm{LW}=$ live weight.

Period $1=07 / 14 / 14$ to $08 / 11 / 14$.

Period $2=08 / 12 / 14$ to $09 / 08 / 14$.

Period $3=09 / 09 / 14$ to $10 / 06 / 14$.

regrowth, since new leaves have higher nutritional value than old ones (VAN SOEST, 1994).

Another factor that may be related to forage ingestion by animals and; consequently, to their performance is forage allowance. HODGSON (1990) suggested that daily FA should be 3 to 4 times higher than forage consumption. According to GARCIA et al. (2014) animals receiving a multimineral mixture in a deferred signal grass pasture during the dry period, presented forage intake of $1.5 \mathrm{~kg}$ of dry matter per $100 \mathrm{~kg}$ of body weight. Even with decreasing FA along the experiment period, the FA in the third period was far above the value proposed by HODGSON (1990). Thus, it is possible to affirm that forage mass was not a limiting factor by the forage intake throughout the experimental period.

Animal performance decreased by about $20 \%$ between the first and the second evaluation periods, and then increased by approximately $50 \%$ to third evaluation period (Table 1 ). Besides the lowest nutritive value of forage (Table 1), the lowest ADG observed in the second period of evaluation, between August and September, could be explained by the lowest PL and highest PD (Table 1). As the animal diet consists primarily of leaf (HODGSON, 1990), the presence of stem and dead material in the grazing horizon limits the bite depth (DIFANTE et al., 2009), resulting in a decrease in forage intake, and consequently, in low animal performance (Da SILVA et al., 2012). Conversely, the more favorable canopy structure for grazing together with higher $\mathrm{CP}$ and IVOMD percentages (Table 1) may explain the highest live weight gain observed in the third period (Table 1).

During the deferred period, B. brizantha 'Marandu' (marandu grass) pasture accumulated greater forage mass than B. decumbens 'Basilisk' (signal grass) pasture (Table 2). Regardless of species, the forage mass was lower than that observed by EUCLIDES et al. (2007) and GARCIA et al. (2014) for the same forage species under a deferred grazing system in the same period. According to MATTOS et al. (2005), the processes of leaf emergence, elongation, and senescence of these two species are severely affected by low water availability in the soil. Thus, the negative water balance soon after the pasture deferral, March to April (Figure 1B), probably interfered substantially with the pasture regrowth, consequently with the amount of forage accumulated, independently of the addition of $50 \mathrm{~kg}$ $\mathrm{ha}^{-1}$ of $\mathrm{N}$. Conversely, despite the positive water balance from May to July (Figure 1A), the minimum temperature was below the ideal for the development of tropical grasses (NELSON \& VOLENEC, 1995), which probably limited the growth of the forage plants during those months. Thus, the combination of these factors limited the forage mass accumulated during the deferred period. However, the animal performance wasn't affected by forage mass since the stocking rate used was adequate to maintain high forage allowance (Table 2).

Signal grass showed greater leaf percentage and leaf mass and lower dead material percentage than marandu grass (Table 2). However, 
Table 2 - Averages, standard error of the mean (SEM) and significance level (p) for canopy height, forage mass, leaf mass, percentages of leaf, stem, dead material, percentages of crude protein (CP), in vitro organic matter digestibility (IVOMD), neutral detergent fiber and acid detergent lignin, and average daily gain (ADG) in signal grass and marandu grass pastures deferred in March and grazed from July to October 2014.

\begin{tabular}{|c|c|c|c|c|}
\hline Variables & Signal grass & Marandu grass & SEM & $\mathrm{p}$ \\
\hline Canopy height $(\mathrm{cm})$ & 27.0 & 33.0 & 1.5 & 0.0085 \\
\hline Forage mass $\left(\mathrm{kg} \mathrm{ha}^{-1}\right.$ of DM) & 2500 & 2840 & 40.8 & 0.0260 \\
\hline Leaf mass $\left(\mathrm{kg} \mathrm{ha}^{-1}\right.$ of DM) & 575 & 390 & 27.4 & 0.0135 \\
\hline Leaf $(\%)$ & 23.6 & 14.0 & 1.1 & 0.0021 \\
\hline Stem $(\%)$ & 21.0 & 19.0 & 0.7 & 0.2001 \\
\hline Dead material $(\%)$ & 62,3 & 69.0 & 1.5 & 0.0342 \\
\hline Crude protein $(\%)$ & 8.1 & 7.0 & 0.2 & 0.0188 \\
\hline IVOMD (\%) & 57.7 & 53.9 & 0.4 & 0.0453 \\
\hline Neutral detergent fiber $(\%)$ & 69.2 & 72.7 & 0.4 & 0.0082 \\
\hline Acid detergent lignin (\%) & 3.0 & 2.9 & 0.1 & 0.4562 \\
\hline $\operatorname{ADG}\left(\mathrm{g}_{\text {animal }}{ }^{-1}\right.$ day $\left.^{-1}\right)$ & 680 & 530 & 0.04 & 0.0089 \\
\hline
\end{tabular}

$\mathrm{DM}=$ dry matter.

the stem percentage was similar for both species. As leaf is the most nutritive part of the forage, it was observed for signal grass greater percentages of IVOMD and CP, and lower NDF content in relation to marandu grass pastures (Table 2). Similarly EUCLIDES et al. (2007) observed higher CP content in the leaves of signal grass compared to marandu grass when subjected to a deferred grazing system of 103 or 135 days.

Consequently, animals grazing signal grass pasture showed a higher average daily gain (ADG) than those grazing marandu grass (Table 2). As supplement intake was similar in both groups, probably the higher nutritive values of the signal grass pasture were responsible for the improved animal performance. Similar performance was obtained for animals supplemented with a multi-mineral mixture in deferred signal grass and marandu grass pastures used during the dry period by GARCIA et al. (2014) and EUCLIDES et al. (2009), respectively.

The estimated ADG of animals (NRC, 1996) as function of the amount of crude protein and energy in marandu and signal grass pastures revealed that daily live weight gains according to the percentage of CP were 0.440 and $0.500 \mathrm{~g}$ animal $^{-1}$ day $^{-1}$, respectively. However, when considering energy $($ IVOMD $=$ total digestible nutrients $(\mathrm{TDN})$, gains would reach 0.500 and $0.680 \mathrm{~g}_{\text {animal }}{ }^{-1}$ day $^{-1}$, respectively. This simulation suggests that the $\mathrm{CP}$ content of the pastures (Table 2) was the main factor limiting animal performance, which was corrected by the supplementation used. Since the ADG observed for animals grazing both forage species (Table 2) was close to the simulated values, considering the energy (IVOMD; Table 2) available in the pastures.

These findings is in accordance with EUCLIDES et al. (2007) who pointed out that nutritive value of deferred pasture is a limiting factor to animal production, and they suggested the importance of animal supplementation to correct, mainly, protein deficiency of those pastures. Another point worth mentioning is the ability of signal grass to maintain higher leaf percentage and nutritive value, after deferred period when compared to deferred marandu grass (Table 2). These characteristic was showed by EUCLIDES et al. (2007).

\section{CONCLUSION}

The deferral of B. brizantha cv. 'Marandu' or B. decumbens cv. 'Basilisk' pastures associated with mineral-misture supplementation are management alternatives for rearing cattle during dry period.

\section{ACKNOWLEDGEMENTS}

To Coordenação de Aperfeiçoamento de Pessoal de Nivel Superior (CAPES), for the firts author financial support.

\section{REFERENCES}

BARIONI, L.G. Embrapa Invernada 1.0. 2011. Available from: <http://www.invernada.cnptia.embrapa.br>. Accessed: Jul. 10, 2014.

DA SILVA, S.C. et al. Grazing behaviour, herbage intake and animal performance of beef cattle heifers on marandu palisade grass subjected to intensities of continuous stocking management. Journal of Agricultural Science, v.151, p.727-739, 2012. 
DIFANTE, G.S. et al. Ingestive behaviour, herbage intake and grazing efficiency of beef cattle steers on Tanzania guineagrass subjected to rotational stocking managements. Revista Brasileira de Zootecnia, v.38, n.6, p.1001-1008, 2009.

EUCLIDES, V.P.B. et al. Biological and economic efficiencies of steers in finishing period fed with supplementary diet in a palisade grass pasture. Pesquisa Agropecuária Brasileira, v.44, n.11, p.1536-1544, 2009.

EUCLIDES. V.P.B. et al. Alternatives for intensification of beef production under grazing. Tropical Grasslands, v.2, p.48-50, 2014.

FOOD AND AGRICULTURE ORGANIZATION FAO. World reference base for soil resources 2006: a framework for international classification, correlation and communication. Rome: FAO, 2006. 145p. (World Soil Resources Report, 103).

EUCLIDES, V.P.B. et al. Deferred pastures of Brachiaria cultivars 'Basilisk' and 'Marandu', in the Cerrados region. Pesquisa Agropecuária Brasileira, v.42, n.2, p.273-280, 2007.

GARCIA, J. et al. Intake, grazing time and performance of steers supplemented in Brachiaria decumbens pastures during the dry season. Semina: Ciências Agrárias, v.35, n.4, p.2095$2106,2014$.

HODGSON, J. Grazing management: science into practice. Essex: Longman Scientific 381 and Technical, 1990. 203p.
LITTELL, R.C. et al. Modelling covariance structure in the analysis of repeated measures data. Statistics in Medicine, v.19, p.1793-1819, 2000 .

MATTOS, J.L.S. et al. Effect of water deficit on the growth of Brachiaria species in greenhouse. Revista Brasileira de Zootecnia, v.34, n.3, p.746-754, 2005.

NATIONAL RESERARCH COUNCIL (NRC). Nutrient requirements of beef cattle. 7.ed. Washington, DC: National Academy, 1996. 242p.

NELSON, C.J. Shoot morphological plasticity of grasses: leaf growth vs. Tillering. In: LEMAIRE, G. et al. (Eds.). Grassland ecophysiology and grazing ecology. Curitiba: CABI Publishing, 2000. p.101-126.

NELSON, C.J.; VOLENEC, J.J. Environmental and physiological aspects of forage management. In: BARNES, R.F. et al. (Eds.). Forages: an introduction to grassland agriculture. Ames: Iowa State University, 1995. v.1, p.55-69.

REIS, R.A. et al. Supplementation as a strategy for the production of the beef quality in tropical pastures. Revista Brasileira de Saúde e Produção Animal, v.13, n.3, p.642-655, 2012.

VAN SOEST, J. Nutritional ecology of the ruminant. Ithaca: Cornell University, 1994. 476p.

WOLFINGER, R. Covariance structure selection in general mixed models. Communications in Statistics \& Simulation and Computation, v.22, p.1079-1106, 1993. 